\title{
Diversity of Yeasts and Their Ethanol Production at high Temperature
}

\author{
Vasana Tolieng ${ }^{1 *}$, Sineenath Kunthiphun ${ }^{2}$, Ancharida Savarajara ${ }^{2}$, Somboon Tanasupawat ${ }^{3}$ \\ ${ }^{1}$ Institute of Biotechnology and Genetic Engineering, Chulalongkorn University, Bangkok 10330, Thailand. \\ ${ }^{2}$ Department of Microbiology, Faculty of Science, Chulalongkorn University, Bangkok 10330, Thailand. \\ ${ }^{3}$ Department of Biochemistry and Microbiology, Faculty of Pharmaceutical Sciences, Chulalongkorn University, Bangkok 10330, Thailand.
}

\begin{tabular}{|c|c|}
\hline ARTICLE INFO & ABSTRACT \\
\hline $\begin{array}{l}\text { Article history: } \\
\text { Received on: } 28 / 06 / 2017 \\
\text { Accepted on: } 23 / 07 / 2017 \\
\text { Available online: } 27 / 02 / 2018\end{array}$ & $\begin{array}{l}\text { Thirty one yeasts isolated from sugarcane juice and process-sediments collected from different area of sugar factory } \\
\text { were screened for ethanol production at } 40^{\circ} \mathrm{C} \text {. The isolates were belonged to } 7 \text { genera, namely Pichia, Ogataea, } \\
\text { Millerozyma, Meyerozyma, Candida, Kluyveromyces and Saccharomyces based on phylogenetic analysis of D1/ } \\
\text { D2 region of the large subunit ribosomal (LSU) RNA gene. The majority of the isolates were identified as Pichia } \\
\text { kudriavzevii (Group IB, } 14 \text { isolates), Ogataea polymorpha (Group II, } 5 \text { isolates), Kluyveromyces maxianus (Group }\end{array}$ \\
\hline $\begin{array}{l}\text { Key words: } \\
\text { Diversity, ethanol, Pichia, } \\
\text { Kluyveromyces, Sacharomy- } \\
\text { ces, thermotolerant yeasts }\end{array}$ & $\begin{array}{l}\text { VI, } 5 \text { isolates), Pichia manshurica (Group IA, } 3 \text { isolates), while the minor isolates were Candida tropicalis (Group V, } \\
1 \text { isolate), Millerozyma farinosa (Group III, } 1 \text { isolate), Meyerozyma caribbica (Group IV, } 1 \text { isolate) and Sacharomyces } \\
\text { cereviseae (Group VII, } 1 \text { isolate). The isolates produced ethanol ranged from } 2.97 \text { to } 57.10 \mathrm{~g} / \mathrm{L} \text { at } 40^{\circ} \mathrm{C} \text {. Isolates G3- } \\
9(1) \text { and G3-3(1), identified as K. marxianus and S. cerevisiae showed high potential for ethanol production, } 57.10 \pm \\
0.23 \text { and } 49.42 \pm 0.34 \mathrm{~g} / \mathrm{L} \text {, respectively. }\end{array}$ \\
\hline
\end{tabular}

\section{INTRODUCTION}

Yeasts are mostly unicellular organisms and can be classified either Ascomycetes or Basidiomycetes. They were distributed in varieties of habitat such as soils, plant surfaces and sugar rich samples including fruits, nectar and sap. Currently, there are approximately 1,500 recognized yeast species listed in the latest edition of The Yeasts (Kurtzman et al., 2011). Yeasts are huge potential in biotechnology for their enable to produce numerous valuable products such alcoholic beverages, food, feed and their applications in chemical, pharmaceutical industries and bioremediation (Satyanarayana and Kunze, 2009; Trama et al., 2014).

Increasing demand of petroleum consumption, depletion of energy reserves and concerning on environmental problems are promoting an effort to develop renewable and sustainability biofuel. Several attempts have been initiated to explore new alternatives

\footnotetext{
${ }^{*}$ Corresponding Author

Vasana Tolieng, Institute of Biotechnology and Genetic Engineering, Chulalongkorn University, Bangkok 10330, Thailand.

E-mail: tvasana@chula.ac.th
}

energy friendly substances. Bioethanol received considerable attention as potentially renewable energy source. It was used to blend or substitute of gasoline due to its high octane number and low emission toxic substances. Bioethanol can produce through microbial fermentation process with high efficiently. At first, bioethanol production was developed using sugar or starchy based substrates such as molasses or cassava as a raw materials and $S$. cerevisiae has been common used as microbial agent for ethanol production at industrial level (Tesfaw et al., 2014). S. cerevisiae strains have several advantages such as high ethanol yield, high tolerance to ethanol and chemical inhibitors however they could produce high ethanol concentration at moderated temperature (25$35^{\circ} \mathrm{C}$ ) (Aditiya et al., 2016).

Exploration, identification and characterization of other potential microorganisms that can produce ethanol at high temperature should be conducted to increase the industrial attractiveness for tropical countries and can apply to simultaneous saccharification process for reducing product inhibition and production costs (Abdel-Banat et al., 2010; Zhu et al., 2012). This study deals with the isolation and characterization of yeasts based on their phenotypic characteristics and phylogenetic 
analysis of D1/D2 region of the large subunit ribosomal RNA gene (D1/D2 LSU) including the ethanol production at higher temperature.

\section{MATERIALS AND METHODS}

\section{Sources and isolation methods}

Seventeen samples of sugarcane juice and processsediments, collected from Thai Sugar industry Co., Ltd, in Kanchanaburi province, Thailand were used for yeast isolation. One gram or $1 \mathrm{~mL}$ of sample was enriched in $5 \mathrm{~mL}$ of GYPE medium ( $2 \%$ glucose, $0.3 \%$ yeast extract, $0.3 \%$ peptone, $0.1 \%$ chloramphenicol (w/v) and 3.0\% ethanol (v/v), $\mathrm{pH} 5.6)$ in $16 \times$ $150 \mathrm{~mm}$ test tubes and incubated at $40^{\circ} \mathrm{C}$ under oxygen limiting condition by wrapping cotton plug of the test tubes tightly with parafilm tape for $72 \mathrm{~h}$. The isolates were re-streaked for purification on GYP agar plates containing $1 \%$ glucose, $0.3 \%$ yeast extract, $0.3 \%$ peptone, $2 \%$ agar and supplement with $0.1 \%$ chloramphenicol (w/v), $\mathrm{pH} 5.6$ and incubated at $40^{\circ} \mathrm{C}, 48 \mathrm{~h}$ under oxygen limiting condition where oxygen were limited using candle jar. The yeast cultures were kept on yeast extract-peptonedextrose (YPD) agar [1\% yeast extract, $2 \%$ peptone, $2 \%$ glucose $2 \%$ agar (w/v), $\mathrm{pH} 5.6]$ at $4{ }^{\circ} \mathrm{C}$ for further study.

\section{Identification methods}

\section{Phenotypic characterization}

Morphological and cultural characteristics of the isolates were investigated on YPD agar plate after incubated under aerobic conditions at $40^{\circ} \mathrm{C}$ for $48 \mathrm{~h}$ (Kurtzman et al., 2011). Carbon assimilation of the isolates was determined using cells grown on YPD agar at $30^{\circ} \mathrm{C}$ for $48 \mathrm{~h}$. Cells of each isolates were suspended in $2 \mathrm{~mL}$ normal saline solution and adjusted the turbidity to obtained 2 McFarland units and $250 \mu \mathrm{L}$ of the suspension was then transferred into $7 \mathrm{~mL}$ API $\mathrm{C}$ medium and mixed gently. The mixture of cell suspension and API C medium $(135 \mu \mathrm{L})$ was inoculated into each cupule of ID32C kit (bioMérieux) and incubated at $30^{\circ} \mathrm{C}$ for $24-48 \mathrm{~h}$. Turbidity of cell grown in ID $32 \mathrm{C}$ kit was determined as positive $(+)$ and negative $(-)$ compared to the control.

\section{Genotypic characterization}

The DNA extraction of cells grown on YPD agar at $30^{\circ} \mathrm{C} 48 \mathrm{~h}$ was carried out according to the procedure described by Lachance et al. (1999). PCR genomic DNA amplification was performed using primers pair NL1 (forward primer: 5'-GCATATCAA TAAGCG GAGGAAAAG-3') and NL4 (reverse: 5' GGT CCGTGT TTCAAGACG 3') as described by Kurtzman and Robnett (1998; 2003). Amplified PCR of LSU D1/ D2 product was purified by ion Kit (Geneaid Biotech Ltd., Taipei, Taiwan). Agarose gel electrophoresis was performed to resolve the amplified using a standard molecular weight marker $100 \mathrm{bp}$ DNA ladder (Fermentas, USA) as DNA marker. The gel was stained with ethidium bromide, visualized under UV light. The purified PCR products were sequenced using ABI Prism ${ }^{\mathrm{TM}}$ Big Dye $^{\mathrm{TM}}$ Terminator Cycle sequence Ready Reaction Kit (Applied Biosystems, Stafford, USA) following the manufacturer's instructions. Sequencing was done with the same primers as used in the PCR reaction. The resultant LSU D1/D2 sequences were edited manually using BioEdit v7.2.5 (Hall, 1999). The LSU D1/ D2 sequences were compared to those online data base available in National Center for Biotechnology Information (NCBI) (http:// www.ncbi.nlm.nih.gov/blast) by Blastn program and were aligned with muscle where gaps and missing data was deleted manually (Edgar, 2004). Neighbor-joining (NJ) phylogenetic tree was constructed using MEGA 7 (Kumar et al., 2016). The Kimura-2parameter model was used to calculate the nucleotide-sequence divergence, and bootstrap values were obtained from 1000 replications (Kimura, 1980; Felsenstein, 1985).

\section{Ethanol production}

The isolated yeast grown on YPD at $40^{\circ} \mathrm{C}$ for $48 \mathrm{~h}$ was inoculated into $250 \mathrm{~mL}$ Erlenmeyer flask containing $50 \mathrm{~mL}$ of fermentation medium [15\% glucose, $0.6 \%$ yeast extract and $0.9 \%$ polypeptone $(\mathrm{w} / \mathrm{v}), \mathrm{pH} 5.0]$ and incubated on rotary shaker $(200$ $\mathrm{rpm})$ at $40^{\circ} \mathrm{C}$ for $24 \mathrm{~h}$. One percent of each cultures was inoculated into $250 \mathrm{~mL}$ flask containing $50 \mathrm{~mL}$ of fresh fermentation medium, and incubated for $24 \mathrm{~h}$ under the above conditions then transferred $10 \%$ of the cultures into $42.5 \mathrm{~mL}$ of the fresh fermentation medium in $50 \mathrm{~mL}$ Erlenmeyer flask and incubated at $40^{\circ} \mathrm{C}$ for $48 \mathrm{~h}$ under oxygen-limiting condition. The cultures were then collected by centrifugation at $5000 \mathrm{rpm}$. The ethanol concentration of the above supernatants was determined by Gas Chromatography as described by Jutakanoke et al. (2014).

\section{RESULTS AND DISCUSSION}

\section{Isolation and identification of isolates}

Thirty one yeast strains were isolated from 17 sugar rich samples collected from different locations in sugar factory (Table 1). They were divided into four major groups and another three minor groups. All isolates were differentiated based on their morphological and cultural characteristics, carbon assimilation ability and D1/D2 region of the large subunit ribosomal (LSU) RNA gene analysis (Tables 1 and 2, Figure 1).

Group I consisted of 17 isolates, G3-1, G3-2 (2), G3-2 (3), G3-4 (1), G3-4 (2), G3-4 (4), G3-6 (11), G3-7, G3-10 (2), G3-12 (1), G3-13 (5), G3-14 (1), G3-14 (2), G3-16 (1), G3-16 (2), G3-17 (1) and G3-17 (3). Cells of isolates G3-1, G3-12 (1), G3-14 (1) were ovoid to cylindrical while colonies were tannish white, smooth, dull and butyrous.

They assimilated N-acetylglucosamine and glucosamine as sole carbon source and showed positive reaction with esculin. Based on $100 \%$ similarity of D1/D2 LSU sequences, isolates G3-1, G3-12(1), G3-14(1) were identified as Pichia manshurica (Group IA) (Table 1). Some Pichia strains were reported as non-Saccharomyces wine yeast such as $P$. farinosa, P. kluyveri and P. terricola (Jolly et al., 2006). Whereas $P$. manshurica was listed as the yeast that was causing of wine spoilage from their capable to produce volatile phenols (Saez et al., 2011). In addition, Pichia strains were the predominant species found in distilleries (Ubeda et al., 2014). The remained 14 isolates were identified as P. kudriavzevii (Group IB) (Table 1) based on $99-100 \%$ D1/D2 LSU sequence similarities. Their cells were ovoid to elongate while colonies were butyrous and light-cream colored. They assimilated $\mathrm{N}$-acetylglucosamine, 
lactic acid, glycerol and glucose. The thermotolerant yeast, $P$. kudriavzevii (synonymously known as Issatchenkia orientalis) was frequently isolated from foods and fruits. In addition, this species had a high potential to produce phytases, a useful enzymes in food processing and agriculture (Chan et al., 2012). Group II contained isolates G3-2(1), G3-4(3), G3-5(2), G3-10(3), G3-17(2) (Table 1).

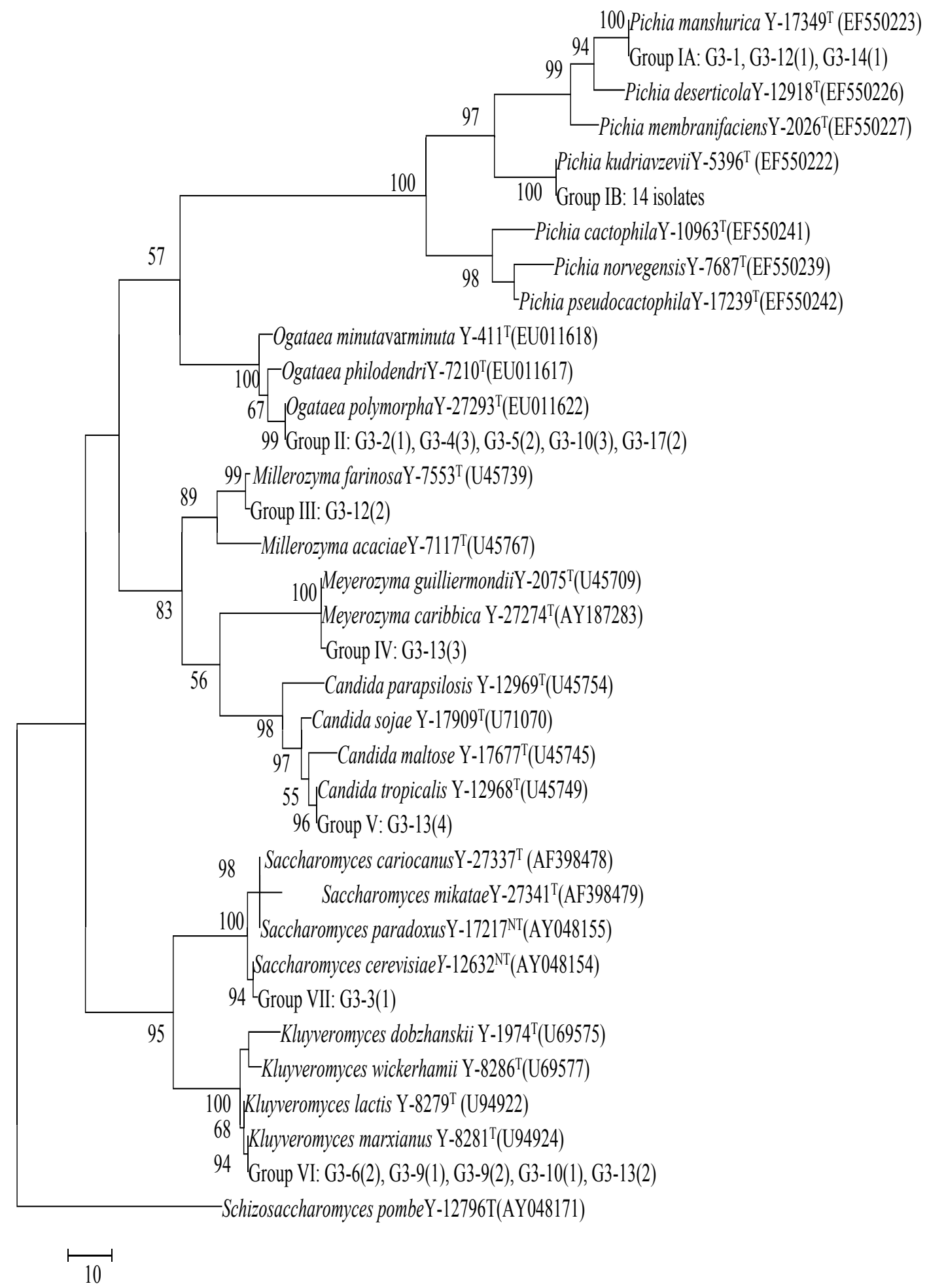

Fig. 1: Phylogenetic tree constructed using the neighbor-joining method showing the position of isolates and related species based on D1/D2 region of the large subunit ribosomal RNA gene sequences. 
Table 1: Source, isolate number, Group, ethanol production, D1/D2 LSU ribosomal RNA gene sequence similarity (\%) and identification.

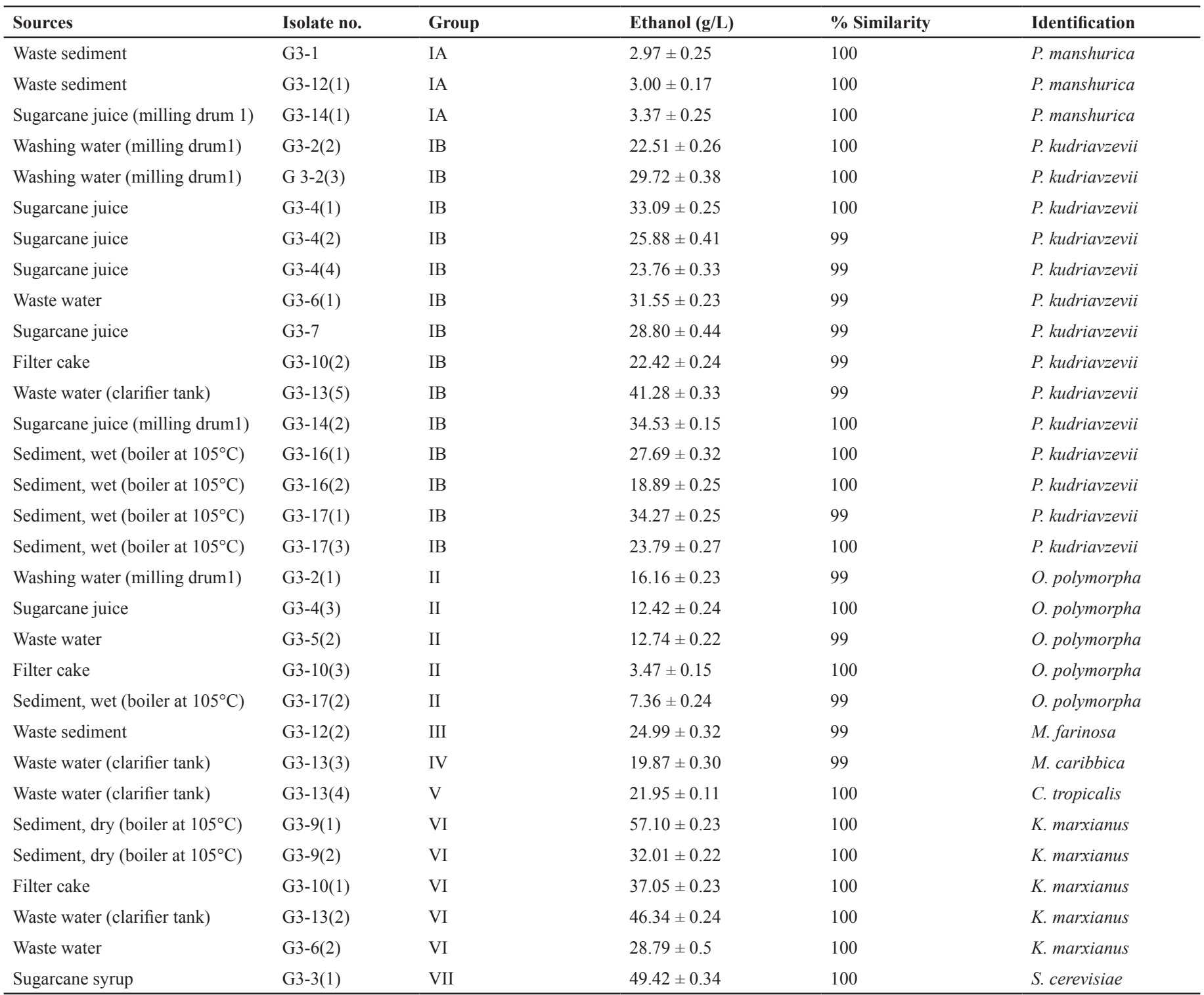

Cells were spherical to elongate. Colonies were butyrous and white to cream colonies. The isolates assimilated D-trehalose, D-mannitol, D-xylose, D-ribose, glycerol, palatinose, erythritol, D-melezitose and D-glucose. They showed $99-100 \%$ similarity of D1/D2 LSU sequences to Ogataea polymorpha NRRL Y-5445 ${ }^{\mathrm{T}}$. Therefore, they were identified as $O$. polymorpha.

This species formerly classified in the genus Hansenula and was thermotolerant microorganism that was able to ferment xylose, which presented in lignocellulosic raw materials. Therefore, they could be applied for biomass based bioethanol production at high temperature (Dmytruk et al., 2008).

Group III contained isolate G3-13(3) (Table 1). Cells were ovoid to elongate. Colonies were white to yellowish white in colored. The isolate assimilated $\mathrm{N}$-acetylglucosamine, D-treharose, D-mannitol, D-ribose, D-glycerol, D-glucose and erythritol (Table 2). Based on 99\% D1/D2 LSU sequence, it was identified as Millerozyma farinosa (syn. Pichia farinosa).
Millerozyma farinosa has been reported as polyol protease enzyme and salt-mediated killer toxin producing strain (Suzuki et al., 2001). Group IV, contained isolate G3-12(2) (Table 1). Cells were ovoid to elongate. Colonies were smooth, circular, convex, white to ivory-white in colored, after grew on YPD agar at $40^{\circ} \mathrm{C}$ for $48 \mathrm{~h}$. The isolate assimilated D-galactose, cyclohexamide, sucrose, $\mathrm{N}$-acetylglucosamine, D-sorbitol, D-xylose and glycerol while D-raffinose, D-trehalose, Potassium-2-ketogluconate, D-glucose and mannitol were assimilated weakly. This stain was identified as Meyerozyma caribbica based on 99\% D1/D2 LSU sequence similarity. M. caribbica was frequently isolated from fermented beverage and could ultilized xylose in hemicellulose hydrolysate with high efficiency (Weinhandl et al., 2014; CassaBarbosa et al., 2015; Papalexandratou and De Vuyst, 2011). Group V contained isolate G3-13(4) (Table 1). Cells were subglobose to ovoid while colonies were dull, smooth surface, soft and creamy, cream-colored or off white to grey. This strain assimilated 
D-galactose, cyclohexamide, sucrose, N-acetylglucosamine, D-maltose, D-treharose, potassium-2-ketogluconate, methyl- $\alpha$ D-glucopyranoside, D-mannitol, D-sorbitol, D-xylose, glycerol, palatinose, D-melezitose, D-glucose and glucosamine. Based on the analysis of D1/D2 LSU sequence similarity (100\%), this strain was identified as Candida tropicalis. This species was thermotolerant yeast that could be growth in various kinds of substrates. It was reported as a useful microorganism for ethanol production from starch and lignocellulosic biomass (Oberoi et al., 2010; Jamai et al., 2007).

Table 2: Phenotypic characteristics of yeast isolates.

\begin{tabular}{|c|c|c|c|c|c|c|c|c|}
\hline \multirow[t]{2}{*}{ Characteristics } & \multicolumn{2}{|c|}{ Group I } & \multirow{2}{*}{ Group II } & \multirow{2}{*}{ Group III } & \multirow{2}{*}{ Group IV } & \multirow{2}{*}{ Group V } & \multirow{2}{*}{ Group VI } & \multirow{2}{*}{ Group VII } \\
\hline & $\mathbf{A}$ & B & & & & & & \\
\hline Cell form & OC & OE & SE & OE & OE & SO & GEC & GOE \\
\hline Colony color & TW & LC & WC & WY & WI & $\mathrm{C}$ & LC & $\mathrm{CB}$ \\
\hline \multicolumn{9}{|l|}{ Carbon assimilation } \\
\hline $\mathrm{N}$-acetylglucosamine & + & + & - & + & + & + & - & - \\
\hline D-Cellobiose & - & - & $-(+1)$ & - & - & - & - & - \\
\hline Cyclohexamide & - & - & $+(-1)$ & - & + & + & + & - \\
\hline Erythritol & - & - & + & + & - & - & - & - \\
\hline Esculin & + & $\mathrm{w}(+4)$ & + & + & + & $\mathrm{w}$ & + & $\mathrm{w}$ \\
\hline D-Galactose & - & - & - & - & + & + & + & + \\
\hline Glucosamine & + & - & - & - & - & + & - & - \\
\hline Glycerol & - & + & + & + & + & + & + & $\mathrm{w}$ \\
\hline methyl- $\alpha$-D-Glucopyranoside & - & - & - & - & - & + & - & + \\
\hline Lactic acid & - & + & - & - & - & - & + & $\mathrm{w}$ \\
\hline Levulinic acid & - & $+(-7)$ & - & - & - & - & - & - \\
\hline Palatinose & - & - & + & - & - & + & - & - \\
\hline Potassium gluconate & - & - & - & $\mathrm{w}$ & - & - & - & - \\
\hline Potassium 2-ketogluconate & - & - & - & - & $\mathrm{w}$ & + & - & - \\
\hline D-Raffinose & - & - & - & - & $\mathrm{w}$ & - & + & + \\
\hline D-Ribose & - & - & + & + & - & - & - & - \\
\hline D-Maltose & - & - & $+(-1)$ & - & - & + & - & + \\
\hline D-Mannitol & - & - & + & + & w & + & - & - \\
\hline D-Melezitose & - & - & + & - & - & + & - & - \\
\hline D-Sorbitol & - & - & $+(-2)$ & - & + & + & + & - \\
\hline L-Sorbose & - & $-(+3)$ & - & - & - & - & - & - \\
\hline Sucrose & - & - & $+(-1)$ & - & + & + & + & \\
\hline D-Trehalose & - & - & + & + & $\mathrm{w}$ & + & - & + \\
\hline D-Xylose & - & + & - & - & + & + & $+(\mathrm{w} 1)$ & - \\
\hline
\end{tabular}

+, positive reaction; -, negative reaction; w, weakly positive. All strains assimilated glucose but did not assimilate L-arabinose, lactose, inositol, l-rhamnose, D-melibiose and sodium gluconate. Numbers in parentheses indicate the number of isolates showing the reaction. GEC, globose, ellipsoidal to cylindrical; GOE, globose, ovoid or elongate; OC, ovoid to cylindrical; OE, ovoid to elongate; SO, cells are subglobose to ovoid; SE, spherical to elongate. TW, Tannish white; LC, light-cream; WC, white to cream; WY, white to yellowish; WI, white to ivory; C, cream; LC, light cream; CB, cream colored to brown.

Group VI consisted of isolates G3-9(1), G3-9(2), G3-10(1), G3-13(2) and G3-6(2) (Table 1). Cells were globose, ellipsoidal to cylindrical while colonies were dull, flat and round, butyrous texture, cream colored to brown or rarely pink. These strains were identified as Kluyveromyces marxianus based on D1/ D2 LSU sequence similarity $(100 \%)$. K. marxianus was known as high biotechnological potential yeast species due to its ability to use a variety of substrates and high growth rate under aerobic conditions. $K$. marxianus was a generally recognized as safe (GRAS) yeast and could ferment ethanol with high efficiently at temperatures of $38-45^{\circ} \mathrm{C}$. So this strain could be used with high potential to produce ethanol commercially by simultaneous saccharification and fermentation (SSF) to reduce production costs (Fonseca et al., 2008; Akaracharanya et al., 2016).

Group VII contained isolate G3-3(1). Cells were globose, ovoid or elongate while colonies were butyrous, flat and light cream colored. The isolate assimilated D-glucose, D-galactose, sucrose, D-raffinose, D-maltose, D-trehalose, methyl- $\alpha$-Dglucopyranoside and eaculin (weakly) but did not assimilate glycerol and lactic acid. Based on D1/D2 LSU sequence similarity $(99 \%)$, this strain was identified as Saccharomyces cerevisiae. $S$. cerevisiae was known for its preference towards glucose. It 
quickly utilized glucose and used other preferred carbon sources after glucose depletion. $S$. cerevisiae lacks the ability to ferment pentose sugars so it could not use for bioethanol production from lignocellulosic biomass (Tesfaw et al., 2014; Weinhandl et al., 2014).

\section{Ethanol production}

All isolates were determined for ethanol production capacity at $40^{\circ} \mathrm{C}$ as shown in Tables 2 . Ethanol production efficiency of Group IA, P. kudriavzevii was varied from 18.89 to $41.28(\mathrm{~g} / \mathrm{l})$. P. kudriavzevii could produce more ethanol than the conventional $S$. cerevisiae at 40 and $45^{\circ} \mathrm{C}$ about 35 and $20 \%$, respectively and cloud fermented ethanol in wide $\mathrm{pH}$ rages when compared with S. cerevisiae (Oberoi et al., 2012). However, group IB, Pichia manshurica showed very low ethanol production at 2.97-3.37 g/L. Ethanol production efficiency of Ogataea polymorpha (group II) were varied from 3.47 to $16.61 \mathrm{~g} / \mathrm{L}$. It was reported that Ogataea polymorpha (syn. Hansenula polymorpha) capable of fermenting xylose, cellobiose and glucose to ethanol at high temperatures $\left(45^{\circ}-50^{\circ} \mathrm{C}\right)$ (Ryabova et al., 2003). So it was counted as one of important yeast that could develop to produce ethanol from lignocellulosic biomass, despite the fact that ethanol yield of this strain still rather low. Millerozyma farinosa G3-13(3) (Group III) produced ethanol at $24.99 \mathrm{~g} / \mathrm{L}$ whereas Meyerozyma caribbica G3-12(2) (group IV) produced ethanol at $19.87 \mathrm{~g} / \mathrm{L}$. Group V, Candida tropicalis G3-13(4) produced $21.95 \mathrm{~g} / \mathrm{L}$ of ethanol from glucose. Group VI, $K$. marxianus could produce ethanol from glucose substrate range from 28.79-57.10 g/L at $40^{\circ} \mathrm{C}$. In this study $K$. marxianus G3-9(1) showed the highest ethanol production (57.10 g/L). Group VII, S. cerevisae G3-3(1) produced $49.42 \mathrm{~g} / \mathrm{L}$ of ethanol that was higher than TISTR 5597 $(34.05 \pm 0.18 \mathrm{~g} / \mathrm{L})$. S. cerevisae was one of important commercial yeast which generally used in beverage, ethanol production and bread making. This yeast species has several advantages on industrial ethanol production due to able to tolerate high ethanol concentration and produce hight ethanol concentration at moderated temperature $\left(37^{\circ} \mathrm{C}\right.$ or less $)$ but it lacked an ability to assimilate xylose that could not be applied for lignocellulosic ethanol fermentation (Tesfaw et al., 2014).

\section{CONCLUSION}

In this present study, Pichia kudriavzevi was the predominant species in the sugar rich area followed by Kluyveromyces maxianus, Pichia manshurica, Ogataea polymorpha, Candida troicalis, Millerozyma farinose, Meyerozyma caribbica and Sacharomyces cereviseae. All isolates were valuated their ethanol fermentation ability and K. marxianus G3-9(1) and G3-3(1) and S. cerevisiae G3-3(1) showed high potential for ethanol production at high temperature $\left(40^{\circ} \mathrm{C}\right)$.

\section{FINANCIAL SUPPORT AND SPONSORSHIP}

This study was financially supported by Ratchadaphiseksomphot Endoement fund 2014 (CU-57-042-EN), Chulalongkorn University.

\section{CONFLICT OF INTERESTS}

There are no conflicts of interest.

\section{ACKNOWLEDGEMENT}

The authors thank Miss Kridsana Krisomdee, Department of Microbiology, Faculty of Science, Chulalongkorn University, for collecting the samples from sugar factories and isolation of the yeast strains.

\section{REFERENCES}

Abdel-Banat BM, Hoshida H, Ano A, Nonklang S, Akada R. High-temperature fermentation: how can processes for ethanol production at high temperatures become superior to the traditional process using mesophilic yeast. Appl Microbiol Biotechnol. 2010; 85(4):861-867.

Aditiya HB, Mahlia TM, Chong WT, Nur H, Sebayang AH Second generation bioethanol production: A critical review. Renew Sustainable Energy Rev. 2016; 66:631-653.

Akaracharanya A, Krisomdee K, Tolieng V, Kitpreechavanich $\mathrm{V}$, Tanasupawat S. Improved SSF-cellulosic ethanol production by the cellobiose fermenting yeast Kluyveromyces maxianus G2-16-1. Chiang Mai J. Sci. 2016; 43(5): 985-996.

Cassa-Barbosa LA, Procópio RE, Matos IT, Filho SA. Isolation and characterization of yeasts capable of efficient utilization of hemicellulosichydrolyzate as the carbon source. Genet Mol Res. 2015; 14(3):11605-11612.

Chan GF, Gan HM, Ling HL, Rashid NA. Genome sequence of Pichia kudriavzevii M12, a potential producer of bioethanol and phytase. Eukaryot cell. 2012; 11(10):1300-1301.

Dmytruk OV, Voronovsky AY, Abbas CA, Dmytruk KV, Ishchuk OP, Sibirny AA. Overexpression of bacterial xylose isomerase and yeast host xylulokinase improves xylose alcoholic fermentation in the thermotolerant yeast Hansenula polymorpha. FEMS Yeast Res. 2008; 8(1):165-173.

Edgar, RC. MUSCLE: multiple sequence alignment with high accuracy and high throughput. Nucleic Acids Res. 2004; 32: 1792-1797.

Felsenstein J. Confidence limits on phylogenies: an approach using the bootstrap. Evolution, 1985; 39(4):783-791.

Fonseca GG, Heinzle E, Wittmann C, GombertAK.The yeast Kluyveromyces maxianus and its biotechnological potential. Appl Microbiol Biotechnol. 2008; 79(3): 339-354.

Hall TA. BioEdit: a user-friendly biological alignment editor and analysis program for Windows 95/98/NT. Nucleic Acids. Symp. Ser. 1999; 41, 95-98.

Jamai L, Ettayebi K, El Yamani J, Ettayebi M. Production of ethanol from starch by free and immobilized Candida tropicalis in the presence of $\alpha$-amylase. Bioresour Technol. 2007; 98(14): 2765-2770.

Jolly NP, Augustyn OP, Pretorius IS. The role and use of nonSaccharomyces yeasts in wine production. S Afr J Enol Vitic. 2006; 27(1): 25-3916.

Jutakanoke R, Tanasupawat S, AkaracharanyaA. Characterization and ethanol fermentation of Pichia and Torulaspora strains. J Appl Pharm Sci. 2014; 4(4):52-56.

Kimura, M. A sample method for estimating evolutionary rate of base substitutions through comparative studies of nucleotide sequences. J Mol Evol. 1980; 16(2):111-120.

Kumar S, Stecher G, Tamura K. MEGA7: Molecular evolutionary genetics analysis version 7.0 for bigger datasets. Mol Bio Evol. 2016; 33:1870-1874.

Kurtzman CP, Robnett CJ. Identification and phylogeny of ascomycetous yeasts from analysis of nuclear large subunit (26S) ribosomal DNA partial sequences. Antonie van Leeuwenhoek. 1998; 73(4):331-371.

Kurtzman CP, Robnett CJ. Phylogenetic relationships among yeasts of the 'Saccharomyces complex' determined from multigene sequence analyses. FEMS Yeast Res. 2003; 3, 417-432.

Kurtzman C, Fell JW, Boekhout T. 2011. The yeasts: a taxonomic study, $5^{\text {th }}$ ed., vol. 1. Amsterdam, the Natherlands: Elsevier Science.

Lachance MA, Bowles JM, Starmer WT, Barker JS. Kodamaea kakaduensis and Candida tolerans, two new ascomycetous yeast species from Australian Hibiscus flowers. Can J Microbiol. 1999; 45(2):172-177. 
Oberoi HS, Vadlani PV, Brijwani K, Bhargav VK, Patil RT. Enhanced ethanol production via fermentation of rice straw with hydrolysate-adapted Candida tropicalis ATCC 13803. Process Biochem. 2010; 45(8):1299-1306.

Oberoi HS, Babbar N, Sandhu SK, Dhaliwal SS, Kaur U, Chadha BS, Bhargav VK.Ethanol production from alkali-treated rice straw via simultaneous saccharification and fermentation using newly isolated thermotolerant Pichia kudriavzevii HOP-1. J Ind Microbiol Biotechnol. 2012; 39(4): 557-566.

Papalexandratou Z, De Vuyst L. Assessment of the yeast species composition of cocoa bean fermentations in different cocoa-producing regions using denaturing gradient gel electrophoresis. FEMS Yeast Research. 2011; 11(7): 564-574.

Ryabova OB, Chmil OM, Sibirny AA. Xylose and cellobiose fermentation to ethanol by the thermotolerant methylotrophic yeast Hansenula polymorpha. FEMS Yeast Res. 2003; 4(2):157-164.

Saez JS, Lopes CA, Kirs VE, Sangorrín M. Production of volatile phenols by Pichia manshurica and Pichia membranifaciens isolated from spoiled wines and cellar environment in Patagonia. Food Microbiol. 2011; 28(3): 503-509.

Satyanarayana T, Kunze G. 2009. Yeast biotechnology: Diversity and Applications. Dordrecht: Springer.

Suzuki C, Ando Y, Machida S. Interaction of SMKT, a killer toxin produced by Pichia farinosa, with the yeast cell membranes. Yeast. 2001; 18(16):1471-1478.
Tesfaw A, Assefa F. Current trends in bioethanol production by Saccharomyces cerevisiae: substrate, inhibitor reduction, growth variables, coculture, and immobilization. Int Sch Res Notices, 2014. Article ID 532852.

Trama B, Fernandes JD, Labuto G, de Oliveira JC, Viana-Niero C, Pascon RC, Vallim MA. The evaluation of bioremediation potential of a yeast collection isolated from composting. Adv Microbio. 2014; 4(12):796.

Úbeda J, Maldonado Gil M, Chiva R, Guillamón JM, Briones A Biodiversity of non-Saccharomyces yeasts in distilleries of the La Mancha region (Spain). FEMS Yeast Res. 2014; 14(4):663-673.

Weinhandl K, Winkler M, Glieder A, Camattari A. Carbon source dependent promoters in yeasts. Microb Cell Fact. 2014; 13(1):5-21

Zhu M, Li P, Gong X, Wang J. A comparison of the production of ethanol between simultaneous saccharification and fermentation and separate hydrolysis and fermentation using unpretreated cassava pulp and enzyme cocktail. Biosci Biotechnol Biochem. 2012; 76(4):671-678.

\section{How to cite this article:}

Tolieng V, Kunthiphun S, Savarajara A, Tanasupawat S. Diversity of Yeasts and Their Ethanol Production at high Temperature. J App Pharm Sci, 2018; 8(02): 136-142. 